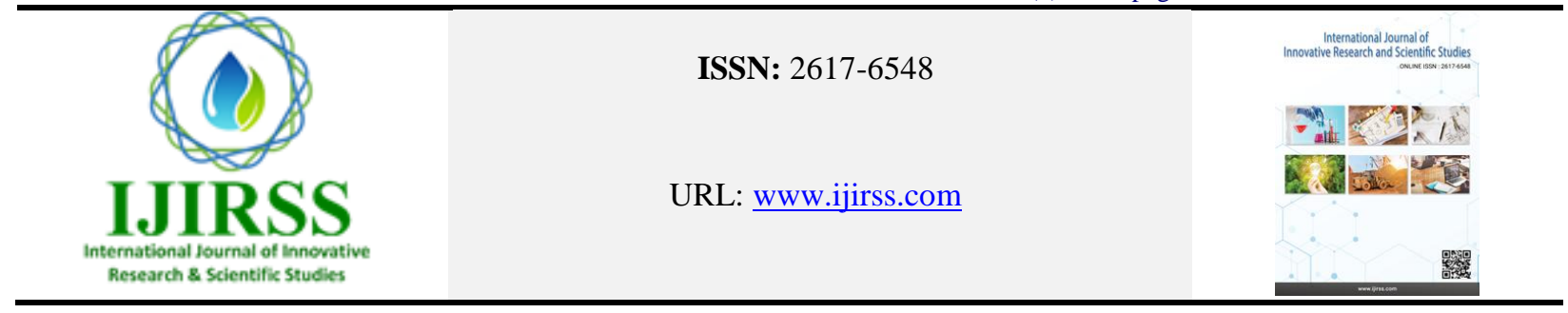

\title{
Role of Literary Works of Mahmoud Tarzi in Improvement of Persian-Dari Contemporary Literature in Afghanistan
}

\author{
Zumaray Wajed \\ Dari Department, Faculty of Language and Literature, Takhar University, Taleqan, Takhar, Afghanistan \\ (Email: zamary.wajed@gmail.com)
}

\begin{abstract}
Literature reflects human feelings and emotions that play a significant role in the process of their lives. The purpose of the study is to clarify the role of Mahmoud Tarzi in the growth and development of contemporary literature in the country in order to motivate others to pay attention to the growth and development of this phenomenon. This study is based on review of the literature. In this review, the author collected articles and books written by prominent authors. The review of the literature revealed that Mahmoud Tarzi played a crucial role in literary, cultural, political, economic, and social transitions to the extent that he considered the founder of contemporary literature in Afghanistan. Moreover, he played a crucial role in transformation and content of classic literature.
\end{abstract}

Keywords: Literature, Contemporary, Poem, Prose, Modernism.

DOI: $10.53894 /$ ijirss.v3i4.44

Funding: This study received no specific financial support.

History: Received: 27 July 2020/Revised: 7 October 2020/Accepted: 29 October 2020/Published: 5 November 2020

Licensed: This work is licensed under a Creative Commons Attribution 4.0 License $(\mathrm{cc}) \mathrm{Er}$

Competing Interests: The author declares that there are no conflicts of interests regarding the publication of this paper.

Transparency: The author confirms that the manuscript is an honest, accurate, and transparent account of the study was reported; that no vital features of the study have been omitted; and that any discrepancies from the study as planned have been explained.

Ethical: This study follows all ethical practices during writing.

\section{Introduction}

Literature as an active and constructive phenomenon, has played a valuable role in human life and ripening public thoughts. In fact, literature is life-sized mirror of culture that reflects different situations of societies. This mirror is made of literary works done by poets and writers [1].

No doubt Persian literature is a branch of world literature which embraces social and moral problems, disapproving cruelty, praising justice and summoning to unity and humanity [2]. Maturity of literature in each society depends on visions and revivals of its poets, authors and intellectuals [3, 4]. Afghanistan is a culture fostering territory and one of trueborn heirs of rich and great civilization of ancient Ariana [5]. Persian literature emerged in this country fifteen centuries ago and has developed in the course of history. Unfortunately, foreigner invasions, desolations, burning libraries and aggressions against culture and knowledge by invaders prevented literature growth. Thus, the Persian literature has experienced many ups and downs [6].

Mahmoud Tarzi is one of the modern-minded and revivalists in Persian language and literature who took important steps to renew content of Persian classic literature and revive contemporary literature [7]. After exile of his family by Amir Abdurrahman Khan from the country, they travelled to India, Turkey, Syria and Saudi Arabia. He lived for many years in Ottoman Empire and became an intellectual, literary man, politician, reflective and freedom seeker. During this period, he 
made close friends from Arab and Turk scholars, thinkers and politicians in Turkey and Arabia. Because of his excess interest in literature, he spent much time in study and translation of works of Turkish authors and scholars [8]. This business caused his motivations for revival and modernism in national literature [9]. Mahmoud Tarzi became acquainted with European civilization and organizations in Damascus and Constantinople institutes and used his experiences in modernization and growth of contemporary literature in Afghanistan. Additionally, he was impressed from Saied Jamal Uddin Afghani and his freedom seeking thoughts. In fact, most of his thoughts were formed under the influence of Saied Jamal Uddin's reflections. When Saied Jamal Uddin went to Istanbul, Mahmoud's father Ghulam Mohammad Tarzi sent him with a letter to Jamal Uddin hopping that Mahmoud can learn from him and be impressed of his thoughts. Mahmoud stayed with Saied Jamal Uddin for several months as a hardworking learner as his emotions and vigilances increased under the education of Eastern Champion. Regarding this issue he writes: "Allama Saied Jamal Uddin was a mine of knowledge. This seven-month companionship was more prolific than seventy years of touring around the world [8].

Anyhow, after death of Amir Abdul Rahman, Mahmoud Tarzi returned to his homeland, and made efforts to develop national literature and other arts. He wrote many articles and recommendations to modify content of classic literature in order to encourage other poets and writers to revivalism. With such style of thinking, he could renew contemporary literature both in content and form, as he was given the title "Father of Contemporary Literature of Afghanistan". Without any doubt he was competent to this title [10]. After his return to the country, Mahmoud Tarzi endeavored to socialize the national literature and connect it to new politics, industry and modern economy. He suffered lots of pains until attained his goals. He got helps by unanimous endeavors of other Afghan poets and authors ripened the semi-ripe literature of this country [9].

\section{Role of Tarzi's Works in Growth of Persian Contemporary Literature}

Mahmoud Tarzi is the first reflective who started revivalism in literature and modernization of language in Afghanistan, as he opened a chapter of critical awakening in discourse of contemporary language and literature [2]. Tarzi had more interest in literature and politics than anything else, so that we can say he loved them. He started writing and translation of literary works while he was a youngster, as he translated the works he thought they will be instructive and beneficial for Afghan people, into Persian-Dari [11]. For example, he translated "Tour of eighty days" or "War of Russia and Japan", to give Afghan people understanding of that mankind can tour around the earth or an Asian country can defeat Russian empire [12].

Anyhow Tarzi is the first translator of modern novel and the first interpreter of poetry in contemporary literature. At the beginning of the book "Paraganda - scattered", he translated a strophe-poem of Zia Pasha (A Turkish poet) from Turkish into Persian-Dari poem, so he had the merit of being pioneer in this realm. The activities he had done, were all innovative, both in writing and translation [13]. He had done many innovative works in field if contemporary literature. For instance, he set forth the discourse on essence of literature in the country. As he wrote literary articles, performed blank verse and simplified writing method. He used colloquial style of language in literature, published literary works of local languages, politicized and socialized literature, permitted technical lexicon to involve Persian poetry, for the first time translated the European novel into Persian-Dari and for the first time he translated foreign poem into Persian poem in contemporary literature of Afghanistan [14].

Additionally, Mahmoud Tarzi can be reckoned as pioneer scholar in several cultural fields in Afghanistan literature, as he set forth simple writing and wrote some articles regarding this issue. He talked about needs for translation of western scientific works into Persian and introduced academic approaches to do this task. He discussed novel and novel writing. First, he translated some novels of French authors "Joel Vern" and "Gustave de Monte Pen" into Persian and published them. He gave a lot of attention to national languages and dialects, as for the first time he recorded and wrote bout Persian dialect of "Hazaragi". He initiated political and social contents in Persian poetry, used words related to modern industry such as; trains, electricity, telegraph, telephone, TV etc... in his poetry and paved the way for any kind of innovation and revival in the future. He founded the first magazine for children "Seraj-ul-Atfal" in the country [15].

Mahmoud Tarzi appreciated women revolution. When his son in law, the king Amanullah came to the reign, he founded first women magazine "Ershad-ul-Naswan" with his wife Asma his brother's daughter "Roh Afza" and published its first volume in March1901 [16]. In addition to above mentioned points, Mahmoud Tarzi is the first reflective scholar who did some works of modern linguistics in Afghanistan, as he presented theories in division of languages, relations of Persian and Pashto languages, their grammars and social functions in Afghanistan. Though all his views were not accurate and acceptable, opening such windows shows his innovative efforts in fields of knowledge and science [14]. In his literary works, Tarzi used plain, artless and logical language that can be understood by the public. Though he had the ability to discuss very complex subjects, brought the essential topics out of magic complexity and expressed them in easy words. He had remarked many points in use of language. For instance, he noticed that big difference between writing and speaking forms, is a weak point of Persian language, meanwhile, in European languages there is less difference between speaking and writing styles. He emphasized on reduction of space between these two styles in Persian language use. This proposal shows that he was well aware of English language change and knew that long before Chaser and Shakespeare, English had the same situation that grammatical rules were ignored in speech and the difference between speaking and writing was so large. Both poets did lots efforts to decrease the space between writing and speaking style of English language [12].

In fact, Tarzi wanted to publicize the call for revival and necessity of learning modern science. He repeatedly calls people to learn new knowledge, as he believed that deliverance of their country from invasion of conquerors and reaching to civilization, depends on acquisition of modern science and attaining knowledge of new industry [12]. Tarzi believed that literature of each country must be mirror of its cultural, political, social and economic situations [17]. Thus, he strived to 
improve the conditions for Persian literature as it can reflect any kind of humanitarian thought. On one hand, he brought perfumed flowers of world and European literature to Afghanistan to plant them in national literature garden, on the other hand, he never forgot that flowers of his homeland were also perfumed and people must enjoy them. He had special attention to local dialects and encouraged poets and writers of his time to use words and expressions of these dialects in their poetry and writings. Poets and writers before Tarzi were loyal to formal language and followed Indian style [12].

Tarzi was a literary champion with new ideas who had brought beneficial thoughts from Turkey (Ottoman Empire) which was center of revivalism in Islamic world. In shor.t time he could extend his thoughts revivalism and made a large circle of revivalist scholars. Their literary activities attracted Prince Amanullah and reached to the royal courts. He published many articles in "Serajul Akhbār" about modernism and the necessity of revivalism in literature, as in short time its popularity extended outside geographical borders of Afghanistan [1, 18]. According to Abdul Hay Habibi. Spread and reflection of Mahmoud-e-Tarzi's thoughts and Serajul Akhbār were the source of inspiring constitutionalism for youths not only inside Afghanistan, but it also flamed desires of constitutionalism and freedom seeking in youth associations in Iran and Central Asia who were suffering cruelty of Russian colonialism [18]. Tarzi worked as the editor and author in second period of "Serajul Akhbār". He was educated under the care of Said Jamal Uddin Afghani and knew the European literature. He could publish thirty-one books and epistles in forms of prose and poem, some of them were translated from Turkish and Arabic literature [19, 20].

\section{Tarzi and Modification to Content of Classical Literature}

Vision of Mahmoud Tarzi regarding content of classical literature differed from views of many other scholars in his time. He tried to renew content of literature as it was the demand of his time. He believed that literature is the best ground for any kind of cultural renaissance. Based on this vision, he decided to modify content of Persian literature, as for long time, it was full of laudatory poetry, praise of love, sexual relations and prisoned in courts of kings. He made efforts to socialize literature and put it in public access as it can reflect social facts, reality, and people's desires. He began to sing blank verse and write articles containing technical lexicon [21, 22]. Doing this, Tarzi began a revolution in literature and changed its classical content. He ignored all classic literary traditions, renewed literary subjects and set a new approach for Persian poetry. Tough he expressed his literary manifest in first volume of "Serajul Akhbār" and claimed that: "the time of poetry and being poem has passed and went', he remained as a poet to the end of his life and published some collections of his poetry such as "Julida" and "Pajmorda". He didn't believe in the vanity of poetry, but he condemned lyric verses praising sexual beauties and recommended to put social facts and people' desires in pivot point of literature. He showed special interest in modern technology and science and encouraged poets and writers to discuss academic and social topics using technical lexicon in any literary genre whether it is prose or poem $[2,14]$.

Tarzi changed form of poetry and novel and he is known as the first writer who replaced mythical story with novel and socialized literature in Afghanistan. He paved the way for studying social situations in the country and reflect them in divine verses of Persian poetry [12, 17, 23]. Among all scholars and poets of his time, Tarzi chose two young poets; Abdul Hadi Dawi and Abdul Rahman Ludin to help him in renewal of national literature. They showed their eager and interest to renew literature ad struggle against resistance of traditionalists. These two scholars were also broad-minded and had traveled abroad many times. They had enlightened mind and knew several foreign languages like Arabic, English, Urdu, as they could translate important works of world literature into national languages and help Tarzi in publication of Serajul Akhbār. It is mentionable that Serajul Akhbār was more significant and richer than today's publications for the sake of variety and value of its contents. Tarzi's colleagues who had common thought, decided to bring important changes in classical content of Afghanistan literature. They wanted to be creative not imitator. This was an important point that made progresses in literary activities of that time [12].

After Mawlawi Khaki Qandahari, Tarzi was the second founder of Serajul Akhbār, that functioned as an informal association of constitutionalists, independence seekers and literary revivalists. Serajul Akhbār had affected Afghan poets and writers such as Mawlawi Abdul Rab, Mohammad Sarwar Wasef Qandahari and Abdul Ali Mostaghni, and changed their literary approaches, as many of them left singing lyric poetry and sang a different tune with social and political subjects $[14,20]$. Though revolts for modification of classical literature content, had begun during the reign of Amir Habibullah and several effective works were done in Persian literature (Eshraqi, 2011: p 309), role of Mamoud-e-Tarzi in this field cannot be ignored. Fazel SHarifi belives; though renewal of literature and revival of Persian poetry had begun in first years of the reign of Amir Habibullah, some historical documents show it had roots in the reign of Amir Sher Ali. It is clear that signs of renewal in literature in the reign of Amir Sher Ali was so weak and uncolored and important works of literary revivalism began during the reign of Amir Habibullah [17, 24].

Anyhow, the activities Mahmoud Tarzi did to modify classical content of literature, on one hand resulted in growth and development of contemporary literature. On the other hand, it helped Afghan people in improvement of their cultural life and raising their political awareness. In Serajul Akhbār, he made efforts to inform Afghans of world cultural events and help them get new sense of literature [15, 25].

\section{Innovations of Tarzi in Persian Contemporary Literature}

Though programs of revivalism in contemporary literature had begun at the beginning of Amanullah's kingdom period in years (1901- 1919), its base stone was put in the reign of his father and predecessor Amir Habibullah [9, 26]. According to Zolmay Hewadmal, revivalism in contemporary literature of Afghanistan is related to enlightening leaders of scholars and constitutionalists of first and second period in the reign of Amir Habibullah. Though constitutionalists of first period were routed and annihilated by Habibullah, efforts of second period constitutionalists resulted in positive changes and 
achievements, as they could end the reign of Habibullah and begin the constitution movement, literary revolution and put the country in highway of civilization and development, so briskness and improvement emerged in literature and national culture bloomed colorful flowers [9].

Anyhow by establishing Serajul Akhbār, Tarzi opened a new style and modern school in contemporary language and literature of Afghanistan. He was the first writer who introduced European literature via Serajul Akhbār, thus he could get the title "Father of Contemporary Press and Literature of Afghanistan" and known as the founder of modern literature in both forms of prose and poem [27]. According to Latif Nazemi (contemporary Persian poet and writer) Mahmoud Tarzi had traversed the way in contemporary literature others couldn't traverse it till that time. Important subjects he focused on, were freedom seeking, home loving, struggle against cruelty and colonialism and thoughts of national unity. He loved terrestrial poetry, used colloquial words in poem and called other poets and writers to do this. He was the first poet who permitted technical lexicon and innovative methods of word derivation from modern industry in literature. As he was a poet, he had the broad knowledge and skill in literature theory and literary criticism, so he was pioneer in poetry theory as well [16].

One of his innovations involved modification to Persian written language. He introduced pure Persian writing system and wrote a leading article in Serajul Akhbār $\left(1^{\text {st }}\right.$ volume, $4^{\text {th }}$ year), using pure Persian lexicon, having no word of any foreign language and translated the phrase "Serajul Akhbār" (which is an Arabic phrase) into Persian as "lamp of Afghani messages" [2]. In addition to his efforts to improve Persian contemporary language and literature, Mahmoud-e-Tarzi, did many activities to enrich Pashto language. For the first time, he called for formalization and teaching of Pashto language, emphasized on its use in formal education. In Serajul Akhbār, he wrote: "[World people] call us Afghans and our territory Afghanistan, as we have special habits, behavior and morality, we also possess a special language which is called "Afghani Language". We should care this language as we take care of our life, strive for its improvement and revision. Not only Afghani language speakers, but all people from different tribes of Afghan nation must learn their national and territorial Afghani language" [6].

Tarzi loved literature and wanted to introduce world literature and technical approaches to his nation in simple language. He wrote an article in Serajul Akhbār ( $3^{\text {rd }}$ volume of $1^{\text {st }}$ year) titling "Knowledge and Learning", beginning his initial message with the questions; what is knowledge? What is learning and sagacity? In this article many words and sayings had been quoted from world famous writers and their views were reflected about importance of knowledge and learning. Its writing method was very simple and easy to understand. This method was unfamiliar for royal secretaries who were expert in writing introductory texts in formal and artistic words, so they condemned Tarzi that he had deviated formal writing customs and Persian grammar. Doing these new activities, he came on the stage of revivalism to call authors to renewal of writing styles. He wanted to awaken his people of world literature and stimulate them to seek development routs. He was not concerned of propagandas from traditional authors who accused him of not understanding Persian grammar. He was a skilled literary man and a master in writing who had not any big claim. He well understood role of literature in public awareness. He played a great role in modification of Persian prose in Afghanistan and introduced modern novel writing to Afghan writers. Before that, Afghan writers had been writing stories and fables in classical forms, which were absolutely different from ones written and published after Tarzi's works. Publishing his first translated novels, he introduced novel writing methods to Afghan writers, as they began a new approach in novel writing and translation of European novels into Persian [8].

It's mentionable that Tarzi's translated novels, aimed enlightening public thoughts, so that people become aware of modern science and new knowledge. For instance, the novels; mysterious island, Paris calamities, eighty days around the world and thousand stones under ocean, were not translated only for enjoyment, but the main goal of translations was to awaken Afghan people understanding of western progresses and discoveries [11,12].

\section{Conclusion}

Mahmoud Tarzi is known as the founder of revivalism school in Persian contemporary literature of Afghanistan who took important steps in improvement and growth of this cultural phenomenon. He hoped his country develop in social, political and cultural fields. In order to attain this goal, he took his first steps towards modernism in national literature successfully. Thus, he is known the most effective character of Afghanistan contemporary literature. As results of this review, the following points are worthy of attention:

- Tarzi was the writer who promoted simple writing and publicized it

- He began translation of novel and he was known as the founder of modern novel writing trend in literature history of Afghanistan.

- Tarzi awaked slept thoughts of Afghan people with his renewals in literature

- Tarzi called his people to learn modern knowledge and science

- He introduced western developments and discoveries to Afghan people, via translations, as the pioneer in this realm

- Tarzi loved literature and strived to socialize its contents in order to be understandable for public

- For the first time in Afghanistan, he set forth linguistic discussions and founded principles of dialectology

- He appreciated national languages and dialects, as he gave great attention to different local dialects, as he was the first scholar who recorded and described Hazaragi Dialect.

- He played a key role in growth of Persian contemporary literature of Afghanistan, as he struggled against traditional resistances and tolerated many difficulties, to achieve his goals.

- He was serious about revivalism and renewal of literature, and encouraged other scholars to join him. 
- Tarzi was the founder of a publication its popularity crossed Afghanistan borders and traversed central and western Asia.

- Tarzi established a new style (blank verse) in Persian poetry, no one had done it before him.

- Tarzi involved colloquial words and technical lexicon into poetry realm and called others to do this, thus he is known as the founder of new styles (simple writing) in Persian prose.

- He set the topics such as independence seeking, home loving, struggle against cruelty, social justice, national unity and necessity of knowledge learning in pivot point of poetry subjects.

- Based on above mentioned achievements, he deserved the title "Father of Afghanistan Contemporary Literature".

\section{References}

[1] R. Rahim, "Homeland, nation, independence and development in the thoughts of Allama Mahmoud Tarzi," in Proceedings of the Conference on the Establishment of Modern Diplomacy in Afghanistan Kabul: Center for strategic studies of the ministry of foreign affairs of the Islamic republic of Afghanistan, 2009.

[2] B. Skhawarz, Tarzi and Serajul Akhbār. Tehran: Erfan, 2007.

[3] S. Bahnasawi, Contemporary Islamic thoughts. translated by Abdul Aziz Salimi. Tehran: Ehsan Publisher, 2016.

[4] W. Bakhtari and M. Shah, In the absence of history. Peshawar: Parnian, 2000.

[5] H. Anoshta and S. Shariati, Hafizullah, Afghanistan in the west. Tehran: Nasim Bukhara, 2003.

[6] M. H. Awrang, "From the distant past to the fall of the Amani government, Summary of Afghanistan in the history of Mir Gholam Mohammad Ghobar," Kabul, Said, 2013.

[7] R. Zaryab, What we wrote. Tehran: Erfan, 2003.

[8] M. E. Andishmand, "Role of Mahmoud-e-Tarzi in enlightening and revivalism of second and third decade of twentieth century," presented at the Collection of Selected Articles from Afghanistan's Modern Diplomacy Conference Kabul: Center for Strategic Studies, MFA, 2009.

[9] S. A. Shahrestani, "Persian-Dari language and literature in Afghanistan. Khat-e-Sewom, (seasonal magazine of cultural, literary and artistic subjects), 1st year,", 2002.

[10] Z. Hewadmal, Growth of Dari language and literature in cultural territory of Pashto language speakers. Kabul: Afghan Independent Authors Nion, 1997.

[11] M. A. Ahmadi, A study of the historical causes of the non-sustainability of the Amani reforms. Kabul: Center for Strategic Studies of the Ministry of Foreign Affairs of the Islamic Republic of Afghanistan, 2009.

[12] A. Q. Qawim, History of ancient literature. Kabul: Said 2019.

[13] L. Nazemi, Mahmoud and revivalism, collection of articles from conference, establishment of Afghanistan modern diplomacy. Kabul: Center for Strategic Studies, MFA 2009.

[14] B. Sakhavarz, Tarzi and Siraj Al-Akhbar. Tehran: Erfan, 2007.

[15] S. J. Husaini, "Inventive and influential politician Mahmoud Tarzi," in Proceedings of the Conference on the Establishment of Modern Afghan Diplomacy, Kabul, Center for Strategic Studies of the Ministry of Foreign Affairs of the Islamic Republic of Afghanistan, 2009.

[16] A. Q. Qawim, A review of contemporary Persian Dari literature. Kabul: Said, 2007.

[17] A. Hashemi Farhadi and Adeleh, "The role of Mahmoud Tarzi and his family in educating girls and women in the Amaniyah period," in Proceedings of the Conference on the Establishment of Modern Afghan Diplomacy Kabul, Center for Strategic Studies of the Ministry of Foreign Affairs of the Islamic Republic of Afghanistan, 2009.

[18] S. A. M. Eshraqi, Historical place of Persian-Dari language. Kabul: Yusufzad, 2011.

[19] R. Barahani, Gold in coper. Tehran: Ketab Zaman, 1968.

[20] A. H. Habibi, Constitutionalism revolution in Afghanistan. Kabul: Governmental Printing House, 1988.

[21] M. Z. Aziz, "The role of governor Allama Mahmoud Tarzi in Afghanistan's independence, promotion of culture, excellence in knowledge, education, unity and solidarity of the People and generalization of the right to speak and write in Afghanistan," in Proceedings of the Conference on the Establishment of Modern Afghan Diplomacy, Kabul, Center for Strategic Studies of the Ministry of Foreign Affairs of the Islamic Republic of Afghanistan, 2009.

[22] S. R. Tarzi, Bibliography of Mahmoud Tarzi collection of selected papers of the conference on the establishment of modern Afghan diplomacy. Kabul: Center for Strategic Studies of the Ministry of Foreign Affairs of the Islamic Republic of Afghanistan, 2009.

[23] A. Shefahi, "The concept of independence in the political history of contemporary Afghanistan," Quarterly Journal of Contemporary Perspective in Foreign and International Politics, vol. 3, 2009.

[24] W. Bakhtari and M. Shah, History of Persian literature, History of Persian language, Due to the efforts of professor Rasoul Rahin. Kabul: Afghanistan Cultural Council, 2006.

[25] N. Amiri, Examples of contemporary Afghan poetry. Kabul: Said, 2006.

[26] A. Chowa. (2019) Commitment and defeat of the King Amanullah in modernization of Afghanistan. Academic-Professional Magazine of Contemporary Look at Field of Foreign and International Politics, 3.

[27] M. Zolfeqar, "Tarzi Thought on the role of women in society," in Proceedings of the Conference on the Establishment of Modern Afghan Diplomacy, Kabul, Center for Strategic Studies of the Ministry of Foreign Affairs of the Islamic Republic of Afghanistan, 2009. 